\title{
The impact of vitamin $D$ deficiency on immune T cells in asthmatic children: a case-control study
}

\author{
This article was published in the following Dove Press journal: \\ Journal of Asthma and Allergy \\ 8 May 2012 \\ Number of times this article has been viewed
}

\author{
Haïfa Maalmi ${ }^{1,2}$ \\ Anissa Berraïes ${ }^{1,2,3}$ \\ Eya Tangour ${ }^{1,2,3}$ \\ Jamel Ammar 1,2,3 \\ Hanadi Abid ${ }^{1,2,3}$ \\ Kamel Hamzaoui ${ }^{1,2}$ \\ Agnes Hamzaoui ${ }^{1,2,3}$ \\ 'Department of Basic Sciences, \\ Medicine School of Tunis, \\ University Tunis El Manar, Tunis; \\ 'Unit Research, Homeostasis and \\ Cell Dysfunction, Ariana; ${ }^{3}$ Department \\ of Pneumopediatry, A Mami \\ Hospital, Ariana, Tunisia
}

Correspondence: Kamel Hamzaoui Medicine University Tunis,

15, Rue Djebel Lakdar,

1007 Tunis, Tunisia

Fax +21671569427

Email kamel.hamzaoui@gmail.com
Background: Vitamin D exerts profound effects on both adaptive and innate immune functions involved in the development and course of autoimmune and inflammatory diseases. As the incidence of vitamin D insufficiency is surprisingly high in the general population, experimental studies have started to investigate whether vitamin D levels (measured as serum 25 hydroxy vitamin D-25[OH]D) are correlated with immune cells and clinical parameters.

Purpose: The aim of the present research was to investigate serum vitamin D status in a casecontrol study in children with asthma and to study associations between vitamin D levels and certain immunological parameters.

Materials and methods: A case control study of thirty-nine children with clinically controlled asthma was enrolled to assess the relationship between serum vitamin D concentrations and disease activity. Vitamin D was assayed with a radioimmunoassay kit. We evaluated the relationship between vitamin D concentrations and forced vital capacity (FVC), forced expiratory volume in 1 second $\left(\mathrm{FEV}_{1}\right)$, and the $\mathrm{FEV}_{1} / \mathrm{FVC}$ ratio. Correlations between inflammatory mediators, Th1, Th2, Th17, and regulatory T cells (Treg) and vitamin D were investigated.

Results: Only $15.38 \%$ of our asthmatic children had a sufficient serum $25(\mathrm{OH}) \mathrm{D}(\geq 30 \mathrm{ng} / \mathrm{mL})$ whereas $80 \%$ of healthy children expressed sufficient levels. Deficient values of vitamin D $(<20 \mathrm{ng} / \mathrm{mL})$ were observed in $17(43.59 \%)$ asthmatic patients $(14.40 \pm 3.30 \mathrm{ng} / \mathrm{mL} ; P=0.0001)$. Deficiency was not observed in controls. Th1/Th2 ratio was significantly correlated to $25(\mathrm{OH})$ $\mathrm{D}$ level $(r=0.698 ; P=0.0001)$. A significant negative correlation was observed between serum interleukin-17 and vitamin D levels in young asthmatics $(r=-0.617 ; P=0.001)$. A significant correlation was observed between $\mathrm{CD} 25^{+} \mathrm{Foxp}^{+}$Treg cells and vitamin $\mathrm{D}$ values in asthmatics $(r=0.368 ; P=0.021)$.

Conclusion: Even in a southern Mediterranean country, hypovitaminosis D is frequent in children with asthma. Our findings suggest that vitamin D is an important promoter of $\mathrm{T}$ cell regulation in vivo in young asthmatics.

Keywords: vitamin D, Th17, Treg cells, asthma, children

\section{Introduction}

Vitamin D deficiency is currently associated with asthma. ${ }^{1-4}$ The protective effects of vitamin $\mathrm{D}$ in asthma could be attributable to its immunomodulatory properties. ${ }^{5}$ Beyond a central role in calcium and bone physiology, vitamin D metabolism, specifically the conversion of $25(\mathrm{OH}) \mathrm{D}$ to the active form of vitamin $\mathrm{D}\left(1,25[\mathrm{OH}]_{2} \mathrm{D}\right)$, has effects on epithelial cell, T-cell, B-cell, and dendritic cell functions, which are important for innate and adaptive immunity. ${ }^{6,7}$ Among the vitamin D-stimulated processes that contribute to tolerance are induction of tolerogenic dendritic cells, ${ }^{7,8}$ development of 
$\mathrm{CD} 4{ }^{+} \mathrm{CD} 25^{+} \mathrm{Foxp}^{+}$regulatory $\mathrm{T}$ (Treg) cells, ${ }^{7}$ activation of T-cell and antigen receptor signalling, ${ }^{8}$ and elaboration of antiinflammatory cytokines, including interleukin-10 (IL-10). ${ }^{9}$ Gene expression profiles of dendritic cells have identified many $1,25(\mathrm{OH})_{2} \mathrm{D}$-regulated transcripts that are central to dendritic cell function. ${ }^{7}$ The observation that $1,25(\mathrm{OH})_{2} \mathrm{D}$ treated human dendritic cells have the capacity to convert CD4 T cells into IL-10-secreting Treg cells and suppress the proliferation of $\mathrm{T}$ cells is particularly provocative in light of the clinical importance of $\mathrm{CD} 4{ }^{+} \mathrm{CD} 25^{+}$Foxp $3^{+}$Treg cells. ${ }^{10}$ Vitamin D has the ability to establish homeostasis between regulatory and suppressor T cell functions to modulate inflammatory process as reported by Chambers and Hawrylowicz. ${ }^{11}$ The active form of vitamin $\mathrm{D}$, ie, $1,25(\mathrm{OH})_{2} \mathrm{D}_{3}$, mediates a shift of antigen-presenting cells (APC) and $\mathrm{CD}^{+} \mathrm{T}$ cells to a less inflammatory profile. ${ }^{6}$ Recently, it was shown that $1,25(\mathrm{OH})_{2} \mathrm{D}_{3}$ significantly increased the secretion of IL-10 and decreased the secretion of IL-6 and IL-17 by immune cells. $1,25(\mathrm{OH})_{2} \mathrm{D}_{3}$ also increased the expression and biological activity of indoleamine 2,3-dioxygenase, mediating a significant increase in the number of CD $4^{+} \mathrm{CD} 25^{+}$Treg cells. ${ }^{11}$ The transcriptional characteristics of $\mathrm{CD}^{+} \mathrm{T}$ cells in young asthmatics indicate that Foxp3 (Treg cells) and RORC (Th17) mRNA expression could be associated with the sustained inflammatory process in asthmatics. ${ }^{12}$

The aim of our study was to correlate serum vitamin D levels with asthma severity in children, and to correlate vitamin D levels with Th17 and Treg cells.

\section{Materials and methods Study subjects}

Thirty-nine children with asthma (aged 6-16 years), who were diagnosed and classified according to Global Initiative for Asthma (GINA) recommendations ${ }^{13}$ and attending the Department of Pediatric Respiratory Disease (Unit Research: Homeostasis and Cell Dysfunction [UR/99/08-40]), A Mami Hospital, Ariana Hospital Tunisia between July 1, 2010 and August 31, 2010, were enrolled in the study during a planned visit. Severity was assessed before treatment. All patients were on regular treatment with inhaled steroids. Control was assessed on clinical and functional criteria. Patients presenting an asthma exacerbation or suffering from comorbidities were excluded from the study. Thirty age and sex-matched children attending pediatric emergency for acute extra respiratory symptoms served as healthy controls (aged 6-16 years, mean 9.2; 20 males). Asthmatic patients were excluded. Children suffering with other chronic diseases were excluded. Selection was made according to clinical criteria. The hospital ethical committee approved the study according to Global Initiative for Asthma guidelines as we recently reported, and the parents and children gave their informed consent. ${ }^{12,13}$

\section{Vitamin D status definitions}

Blood withdrawal was performed between July and August, 2010. Immune tests and serum for vitamin D measurement were retrieved at the same time, and cellular assays were performed on the day of blood collection. The collected serum was immediately shielded from direct light and stored at $-20^{\circ} \mathrm{C}$. At the end of the study, all samples were analyzed simultaneously. Serum concentrations of $25(\mathrm{OH})$ D were assayed with a radioimmunoassay kit (Dia-Sorin, Stillwater, MN). Vitamin D level values were used as a continuous variable and were categorized in descriptive analyses as desirable (or sufficient) when scores were at least 30 to $40 \mathrm{ng} / \mathrm{mL}$ ( 75 to $100 \mathrm{nmol} / \mathrm{L}$ ), insufficient between 20 and $30 \mathrm{ng} / \mathrm{mL}$ (50 and $75 \mathrm{nmol} / \mathrm{L}$ ) and deficient when $<20 \mathrm{ng} / \mathrm{mL}$, as previously recommended. ${ }^{3,14}$

\section{Lymphocytes subsets T cell phenotyping}

Lymphocytes were isolated from peripheral blood drawn from 39 asthmatic patients and 30 healthy children. Peripheral blood mononuclear cells (PBMC) were isolated by Ficoll Hypaque gradient centrifugation (Histopaque ${ }^{\circledR}$; Sigma Aldrich, Zwijndrecht, The Netherlands). $\mathrm{CD}^{+} \mathrm{T}$ cells were selectively isolated with RosetteSep ${ }^{\circledR}$ (Stem Cell Technologies, Grenoble, France). The method for intracellular staining of $\mathrm{CD}^{+}$ T-cell subsets has been described in detail previously. ${ }^{15,16}$ The following monoclonal antibodies were used: fluorescein isothiocyanate (FITC)-labeled anti-interferon-gamma (anti-IFN- $\gamma$ ), phycoerythrin (PE)-labeled anti-IL-4, PEconjugated anti-IL-10 (all from BD Biosciences, San Jose, CA) or PE-labeled anti-IL-17 (R\&D Systems, Minneapolis, $\mathrm{MN})$. Based on intracytoplasmic staining, the phenotypes within CD4+ cells were determined as follows: Th1 cells, CD4 ${ }^{+}$IFN- $\gamma^{+}$IL-4-; Th2 cells, CD4 $4^{+}$IFN- $\gamma^{-}$IL-4 $4^{+}$; Tr1 (Type 1 regulatory T) cells, $\mathrm{CD}^{+}{ }^{+} \mathrm{IL} 10^{+}$; and Th17 cells, $\mathrm{CD}^{+}{ }^{+} \mathrm{IL} 17^{+}$. Cell surface (CD4, CD25) and intracellular (Foxp3) staining was carried out on freshly isolated PBMCs from heparinized blood, as we reported recently. ${ }^{17}$ Lymphocytes were gated on the basis of their forward and side scatter properties by using FACSCalibur flow cytometry (Becton Dickinson, San Jose, CA). The data were analyzed using CellQuest software (Becton Dickinson). The following reagents were used: 
Ficoll and CD4-FITC monoclonal antibody (Sigma Aldrich, St Louis, MO); CD25-PC5 (Immunotech, Marseille, France); Foxp3-PE, clone: PCH101 (eBioscience, San Diego, CA); and an intracellular staining kit (eBioscience).

\section{Plasma cytokines}

Plasma IL-17, IL-6, and IL-10 concentrations were measured by enzyme-linked immunosorbent assay (using reagent kits from R\&D Systems).

\section{Statistical analysis}

Since plasma cytokine concentrations were not in a Gaussian distribution, the Mann-Whitney rank sum test was used to assess the differences in cytokine concentrations in asthmatic patients and control subjects. The Pearson correlation test was used to ascertain the correlation among plasma cytokine concentrations. All analyses were performed using SPSS statistical software for Windows (version 9.0; SPSS Inc, Chicago, IL). A probability of $P<0.05$ was considered as significant. Unless otherwise specified, results in the figures are expressed as median (interquartile range: 25 th, 75 th, 10th and 90th percentiles; the 50th percentile represents the median).

\section{Results \\ Demographic data on patients and healthy controls}

Data of asthmatic patients are depicted in Table 1. The severity of asthma in this group of patients was presented according to GINA guidelines. The severity of asthma was

Table I Patients' characteristics

\begin{tabular}{ll}
\hline Characteristic & Data \\
\hline Number of subjects & 39 \\
Sex & \\
$\quad$ Male & $(68.4 \%)$ \\
Body weight (kg) & $32.7(26-45)$ \\
Age & $9.8(6-16)$ \\
Positive skin tests results & $68.4 \%$ \\
FVC (\%) & $88.38(58-1 / 2)$ \\
FEV,$(\%)$ & $92.74(53-120)$ \\
FEV,/FVC & $0.9(0.79-1)$ \\
Passive smoking & $47.3 \%$ \\
Severity & \\
Mild persistent & $60.5 \%$ \\
Moderate persistent & $36.8 \%$ \\
Severe persistent & $2.7 \%$ \\
\hline
\end{tabular}

Abbreviations: $\mathrm{FEV}_{1}$, forced expiratory volume in I second; FVC, forced vital capacity. depicted as mild in $60.5 \%$, moderate in $36.8 \%$, and severe in $2.7 \%$. Considering the low number of severe asthmatics, they were included with moderate asthmatics in the study. No difference was observed in the body weight between asthmatic children $(32.7 \mathrm{~kg}$; range: $26-45)$ and the healthy control group (36.8 kg; range: 29-47).

\section{Vitamin D levels in asthmatic patients and healthy controls}

The healthy subjects and asthmatic children do not differ in sex and age. There was no significant difference in mean vitamin $\mathrm{D}$ serum levels between healthy controls $(23.30 \pm 4.57 \mathrm{ng} / \mathrm{mL})$ and patients $(20.89 \pm 7.51 \mathrm{ng} / \mathrm{mL} ; P=0.12)$. However, when patients and controls were divided according to vitamin D classes, significant differences were observed (Table 2). Sufficient vitamin D levels (33.83 $\pm 3.31 \mathrm{ng} / \mathrm{mL}$; range: $30-38 \mathrm{ng} / \mathrm{mL})$ were observed in six asthmatics (15.38\%). Insufficient levels were found in $16(41 \%)$ patients $(22.94 \pm 2.94 \% \mathrm{ng} / \mathrm{mL}$; range: 20-29.2 ng/mL), and deficient values (14.40 $\pm 3.30 \mathrm{ng} / \mathrm{mL}$; range: $9.7-19.7 \mathrm{ng} / \mathrm{mL}$ ) were observed in 17 patients $(43.59 \%)$. Healthy controls $(\mathrm{n}=30)$ were either sufficient $(80 \%)$ $(31.83 \pm 2.64 \mathrm{ng} / \mathrm{mL}$; range: $30-37 \mathrm{ng} / \mathrm{mL})$ or insufficient $(20 \%)(21.20 \pm 1.12 \mathrm{ng} / \mathrm{mL}$; range: $20.8-29.8 \mathrm{ng} / \mathrm{mL})$. No deficiency was observed in the controls.

\section{Vitamin D serum concentrations depending on clinical data}

Vitamin D level in asthmatics (sufficient, insufficient, and deficient) was studied according to the disease severity (mild and moderate/severe asthma). Patients with moderate asthma expressed lower vitamin D levels $(14.67 \pm 3.20 \mathrm{ng} / \mathrm{mL})$ than mild asthmatics did $(26.10 \pm 5.85 \mathrm{ng} / \mathrm{mL} ; P=0.0001)$ (Figure 1).

Serum levels of 25(OH)D were slightly associated with forced vital capacity (FVC) percent predicted $(r=0.358$; $P=0.025)$. Nonsignificant correlation was observed between percentage of forced expiratory volume in 1 second $\left(\mathrm{FEV}_{1}\right)$ predicted and serum levels of vitamin D $(r=0.319$; $P=0.0507)$. No correlation was observed between $\mathrm{FEV}_{1} / \mathrm{FVC}$

Table 2 Comparison of vitamin D levels in asthmatic patients and controls

\begin{tabular}{lll}
\hline Vitamin D levels & Patients & Controls \\
\hline Deficient $(<20 \mathrm{ng} / \mathrm{mL})$ & 17 & 0 \\
Insufficient $(20-29 \mathrm{ng} / \mathrm{mL})$ & 16 & 6 \\
Sufficient $(\geq 30 \mathrm{ng} / \mathrm{mL})$ & 6 & 24 \\
\hline
\end{tabular}

Notes: Fisher test, $P=0.000$; Chi squared test for linear trend $=30.303, P=0.000$. 


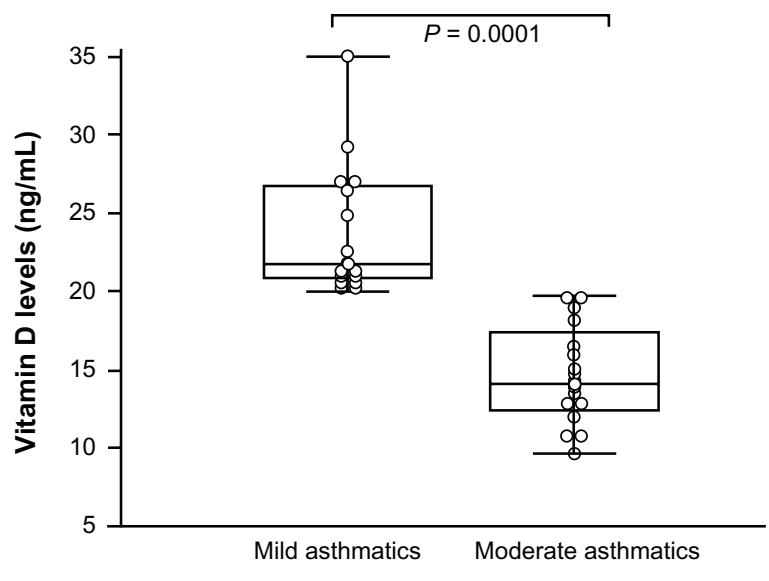

Figure I Vitamin D concentrations of asthmatic patients.

Notes: Box and whiskers plots of vitamin $D$ concentrations of normal controls $(n=30)$ and asthmatic patients $(n=39)$. The medians are indicated by a line inside each box, the 25th and 75th percentiles are indicated by the box limits, and the lower and upper error bars represent the 10th and 90 th percentiles, respectively. The mean values were compared and the $P$ values are indicated in the figure. Moderate asthmatics expressed lower vitamin $D$ levels than mild asthmatics did. Mann-Whitney rank sum tests assessed the difference between mild and moderate asthmatic patients.

and vitamin D. No correlation was found between weight status and vitamin D level.

\section{Serum concentrations of proinflammatory cytokines}

Asthmatic patients showed higher serum IL-17 (18.5 pg/mL; range: 9.75-22.46) and IL-6 (14.72 pg/mL; range: 10.56-18.62) concentrations than healthy controls (IL-17: $10.5 \mathrm{pg} / \mathrm{mL}$; range: $0.08-14.82$; IL-6: $2.75 \mathrm{pg} / \mathrm{mL}$; range: $0.02-8.43)$. The differences were statistically significant (IL-17: $P=0.001$; IL-6: $P=0.002)$. There was no correlation between serum concentrations of IL-6 and vitamin D levels (Figure 2A). A significant negative correlation was observed between IL-17 and vitamin D levels in young asthmatics $(r=-0.617$; $P=0.001$ ) (Figure 2B).

\section{Intracellular cytokines ThI and Th2 in peripheral $\mathrm{T}$ helper cells}

The percentage of IFN- $\gamma$-producing $\mathrm{CD}^{+}$Th1 cells was found to be significantly higher in healthy children $(20.37 \% \pm 4.4 \%$; range: $10.5 \%-27 \%)$ than in asthmatic patients $(6.62 \% \pm 3.46 \%$; range: $2.0 \%-13.8 \% ; P=0.0001$ ) (Figure $3 \mathrm{~A}$ ). A significant difference was observed in the percentage of IL-4-producing $\mathrm{CD}^{+}$Th2 cells between healthy controls $(0.92 \% \pm 0.59 \%$; range: $0.33 \%-1.9 \%)$ and asthmatics $(0.617 \% \pm 0.35 \%$; range: $0.21 \%-1.7 \% ; P=0.0035$ ) (Figure 3B). The Th1/Th2 ratios of normal controls were significantly higher $(27.26 \% \pm 14.35 \%$; range: $9.5 \%-27.3 \%$ ) than those of asthmatic children (13.48\% $\pm 8.55 \%$; range: $2.15 \%-39.4 \% ; P=0.0001)$
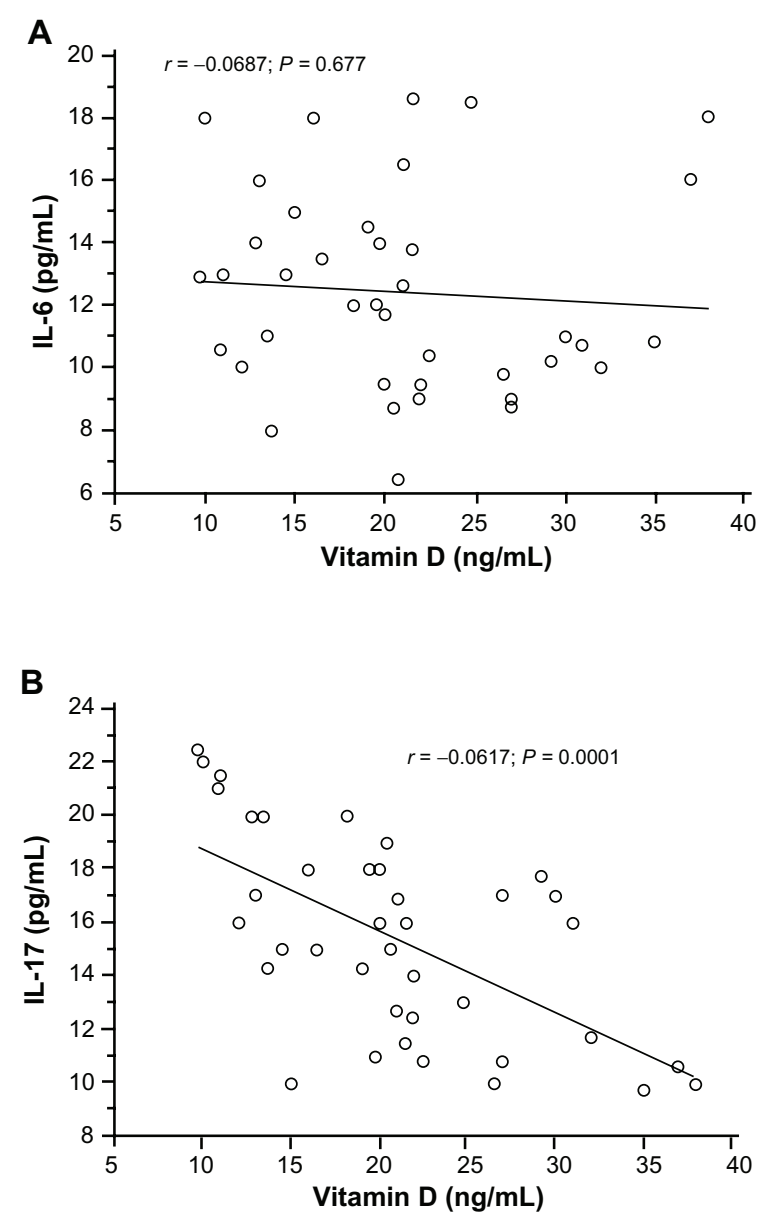

Figure 2 Correlation between vitamin D level and serum IL-6 (A) and serum IL- I7 (B) using, Pearson's correlation coefficient.

Notes: Significant positive correlation was observed for serum IL-17 level $(r=0.617 ; P=0.000 \mathrm{I})$. No correlation was found between serum IL-6 vitamin D levels $(r=0.068 ; P=0.677)$.

Abbreviation: IL, interleukin.

(Figure 3C). A significant positive correlation was observed between $25(0 \mathrm{H}) \mathrm{D}$ levels and Th1/Th2 ratios in asthmatic children ( $r=0.698 ; P=0.0001)$ (Figure 3D).

\section{Intracellular cytokines TrI and Th I7, in peripheral $\mathrm{T}$ helper cells}

Th17 (IL-17) and Tr1 (IL-10) by CD4 ${ }^{+} \mathrm{T}$ cells were assessed depending on intracellular cytokine expression. In asthmatic patients, the median percentage of IL- $10^{+}$cells within the $\mathrm{CD}^{+}$ T cell compartment $(0.50 \% \pm 0.21 \%$; range: $0.2 \%-0.95 \%)$ and the percentage of IL- $17^{+}$cells were decreased $(1.048 \% \pm 0.48 \%$; range: $0.23 \%-1.8 \%$ ) compared to healthy controls (IL-10 $0^{+}$ cells, $1.39 \% \pm 0.85 \%$, range: $0.5 \%-3.4 \%$; IL- $17^{+}$cells, $0.44 \% \pm 0.20 \%$; range: $0.21 \%-0.99 \% ; P=0.0001$ ).

A significant positive correlation was observed between serum $25(\mathrm{OH}) \mathrm{D}$ levels and the $\mathrm{IL}-10^{+} \mathrm{CD} 4^{+} \mathrm{T}$ cells $(r=0.428$; $P=0.0081)$. No correlation was found between IL- $17^{+} \mathrm{CD} 4^{+}$ 


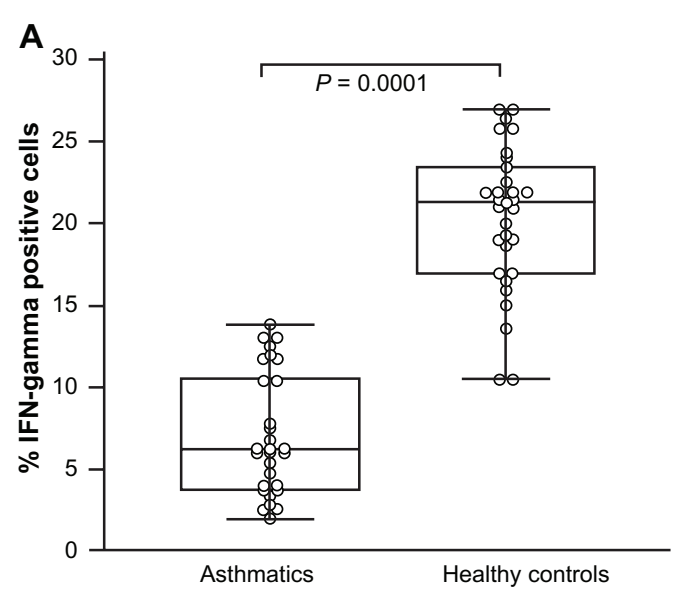

B

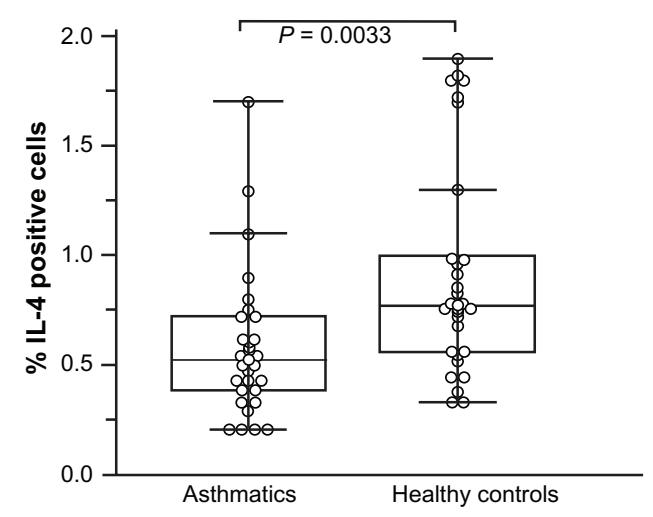

C

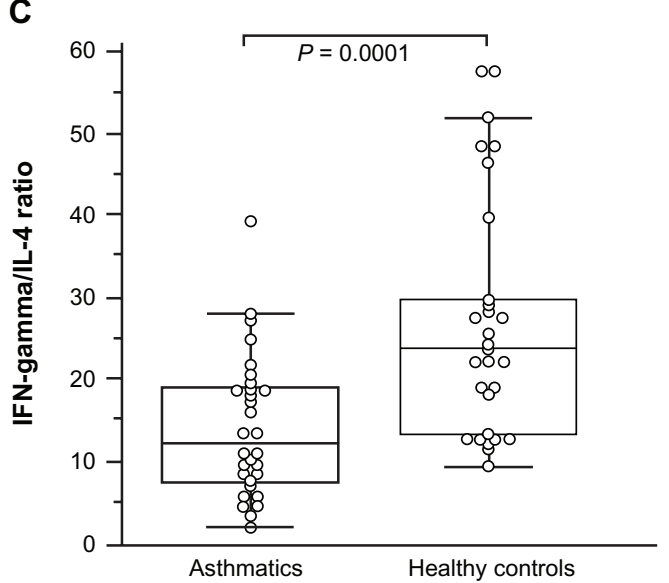

D

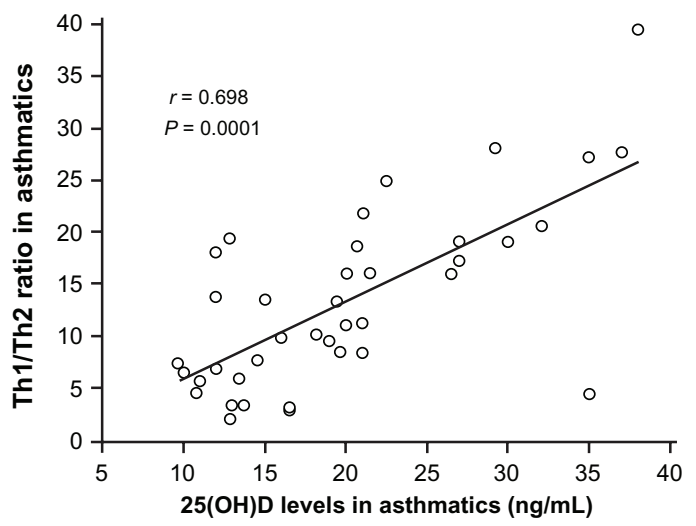

Figure 3 Intracellular ThI and Th2 cytokines. (A-D) Box and whiskers plot of (A) percentage of interferon-gamma (IFN- $\gamma$ ) producing cells; (B) percentage of IL-4 producing cells; and (C) the ratio of ThI/Th2 cytokine (interferon-gamma [IFN- $\gamma]$ and IL-4) determined by Fast Immune Cytokine System for normal controls $(\mathrm{n}=30$ ) and asthmatic patients $(n=39)$. The medians are indicated by a line inside each box, the 25 th and 75 th percentiles are indicated by the box limits, and the lower and upper error bars represent the 10th and 90th percentiles, respectively. The mean values were compared and the $P$ values are indicated at the figure. (D) Correlation between ThI/Th2 ratio and vitamin D levels in asthmatic patients using Pearson's correlation coefficient.

Note: Mann-Whitney rank sum test assessed the differences between controls and patients.

Abbreviation: IL, interleukin.

cells and vitamin D levels $(r=0.123 ; P=0.23)$. Tr1/Th17 (IL-10 producing $\mathrm{CD}^{+}$cells/IL-17 producing $\mathrm{CD}^{+}$cells) ratio was significantly decreased in the asthmatic children compared with the healthy controls (Figure 4).

\section{Regulatory $T$ cells correlate with vitamin D level}

We have recently reported that children with asthma expressed low percentages of Treg cells. ${ }^{17}$ Patients studied for their serum vitamin D levels were investigated for their $\mathrm{CD}^{+} \mathrm{T}$ cells expressing Treg cells. Treg cells were evaluated in the peripheral circulation of 39 asthmatic patients. Regulatory cells within the $\mathrm{CD} 4^{+} \mathrm{T}$ cell compartment were defined as CD2 $5^{\text {high Foxp }} 3^{+}$cells. The median percentage of $\mathrm{CD} 25^{\text {high }}{ }^{2}$ oxp $3^{+}$Treg in the $\mathrm{CD}^{+}{ }^{+} \mathrm{T}$ cell compartment was decreased $(0.75 \% \pm 0.37 \%$; range: $0.2 \%-1.9 \%)$ compared to healthy children $(2.20 \% \pm 0.88 \%$; range: $0.98 \%-3.9 \%$; $P=0.0001$ ) (Figure 5A). A significant correlation was observed between the percentage of CD25 ${ }^{\text {high }}$ Foxp $3^{+}$ Treg cells and vitamin D values in asthmatics $(r=0.368$; $P=0.021$ ) (Figure 5B). The asthmatic children, whatever their vitamin $\mathrm{D}$ value, expressed decreased Treg cells compared with the healthy children $(2.64 \% \pm 0.28 \%$; $P=0.0028)$. A significant positive correlation was observed between vitamin D and IL-10 levels in asthmatics $(r=0.428$; $P=0.008)$. 


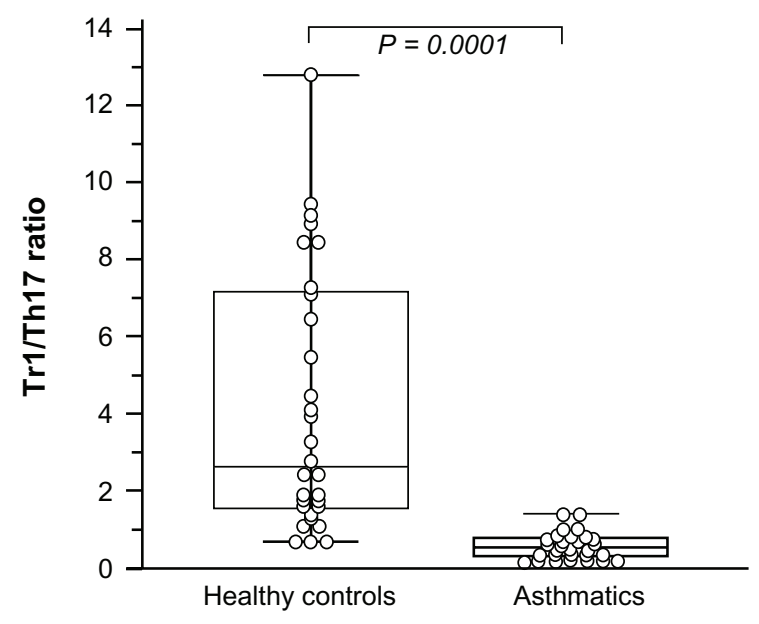

Figure 4 Intracellular Type I regulatory T (TrI) cells (IL-I0) and ThI7 (IL-I7) cytokines $\mathrm{CD}^{+}$production.

Notes: Box and whiskers plot of $\mathrm{Tr}$-producing cells/Th I7-producing cells ratio in asthmatic patients and healthy children. $\mathrm{TrI}$ and $\mathrm{Th} / 7$ cytokine were determined by fast immune cytokine system from normal controls $(n=30)$ and asthmatic patients $(n=39)$. The medians are indicated by a line inside each box, the 25 th and 75th percentiles are indicated by the box limits, and the lower and upper error bars represent the 10th and 90th percentiles, respectively. The mean values were compared and the $P$ values are indicated.

\section{Discussion}

Contrasting levels of vitamin $\mathrm{D}$ have been found in asthmatics. In our report, $43 \%$ of asthmatics were deficient, and $41 \%$ have insufficient vitamin D levels. The decrease in vitamin level was associated with the severity of the disease.

In agreement with a previous observation of Black and Scragg, ${ }^{18}$ the data from our study confirm that serum $25-\mathrm{OH}$ vitamin $\mathrm{D}$ is significantly and positively correlated with FVC. No correlations were observed with $\mathrm{FEV}_{1}$ or $\mathrm{FEV}_{1} / \mathrm{FVC}$. Recently, Zosky et al reported that vitamin D deficiency decreased lung functions. ${ }^{19}$ Similarly, Li et al reported that vitamin D deficiency was highly prevalent in Chinese asthma patients, and vitamin D status was correlated with lung function. ${ }^{1}$

The results for the asthmatic subjects in this study were in accord with those reported by Chinellato et al, who found that hypovitaminosis $\mathrm{D}$ is frequent in children with asthma who live in a Mediterranean country and that lower levels of vitamin D are associated with reduced asthma control. ${ }^{2}$ Vitamin D insufficiency was also reported to be common in a population of North American children with mildto-moderate persistent asthma and is associated with higher odds of severe exacerbation over a 4 -year period. ${ }^{4}$

This is the first study to investigate the correlation between vitamin $\mathrm{D}$ status and the composition of the $\mathrm{T}$ cell compartment in vivo in asthmatic patients. Treg cells in the peripheral blood of asthmatic patients were significantly
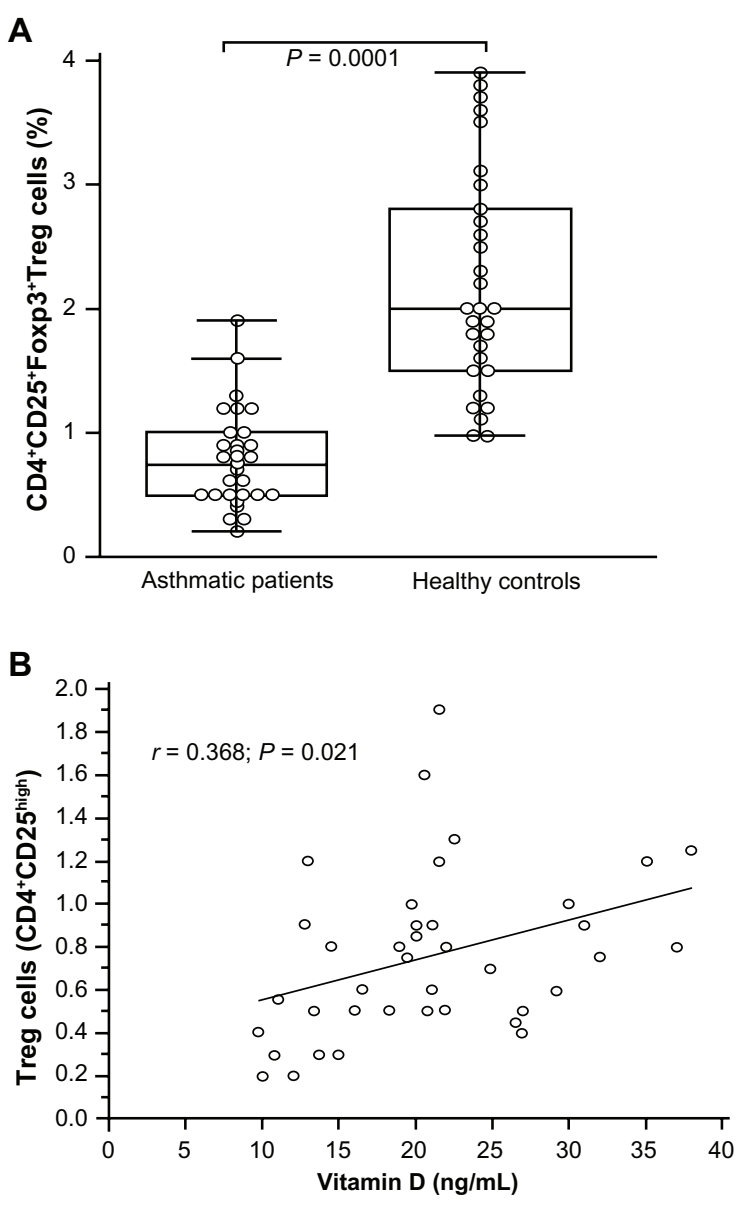

Figure $5 \mathrm{CD}^{2} 5^{+} \mathrm{Foxp}^{+}$Treg in the $\mathrm{CD}^{+} \mathrm{T}$ cell compartment. Box and whiskers plot of percentage of CD25+Foxp3 $3^{+}$Treg in the CD4+ $4^{+}$cells $(\mathbf{A})$. The medians are indicated by a line inside each box, the 25 th and 75 th percentiles are indicated by the box limits, and the lower and upper error bars represent the 10th and 90th percentiles, respectively. Correlation between $\mathrm{CD} 25^{+} \mathrm{Foxp} 3^{+}$Treg cells and vitamin $D$ levels in asthmatic patients using Pearson's correlation coefficient (B).

Note: Mann-Whitney rank sum test assessed the differences between controls and patients.

correlated with vitamin D status. The decreased Th1/Th2 ratio reflected a skewing of the IFN- $\gamma / \mathrm{IL}-4$ balance. Our data indicate that low serum 25(OH)D levels are associated with elevated inflammatory mediators and less regulated $\mathrm{T}$ cell compartments in asthmatic patients.

Several studies suggested that vitamin D deficiency could lead to immune malfunctioning. ${ }^{19,20}$ Although the exact mechanisms of lower vitamin D levels in chronic inflammatory states are not yet elucidated in asthma, this deficit probably interferes with immunoregulatory functions of vitamin D. Immune cells ( $\mathrm{T}$ and B lymphocytes, macrophages and dendritic cells) express vitamin D receptors (VDR) and are affected by vitamin $\mathrm{D}$ deficiency during their maturation process.

Disturbances in vitamin D homoeostasis may contribute to the inflammatory process in asthma. Th1, Th2, and Treg 
cells have been shown to express the vitamin D receptor and to be vitamin D targets. ${ }^{21-23}$ The development of certain immune cells requires the expression of VDR both intrinsically and extrinsically as reported by Yu and Cantorna and Maruotti and Cantatore. ${ }^{24,25}$ Recently, the effect of vitamin D on innate immunity-mediated inflammation, enhancing the antimicrobial properties of immune cells, such as monocytes and macrophages, has been demonstrated. ${ }^{24,25}$ In addition, vitamin $\mathrm{D}$ directly affects $\mathrm{T}$ cell responses by inhibiting the production of Th1 cytokines (IL-2 and IFN- $\gamma$ ), Th17 cytokines (IL-17), and by stimulating Th2 cytokine production (IL-4). Moreover, vitamin D influences the maturation of dendritic cells. ${ }^{22}$ In asthma, vitamin $\mathrm{D}$ could be considered an important mediator, in which fluctuation is correlated to the inflammatory state of the disease.

VDR may function as a regulator of asthma and atopy susceptibility. ${ }^{26} \mathrm{~A}$ strong association between genetic variants at the VDR locus and asthma/atopy in a Quebec cohort was reported. ${ }^{27}$ Along with other known asthma risk genes such as ADAM33, ${ }^{27}$ TLR, ${ }^{28}$ and RANTES, ${ }^{29}$ the addition of VDR involvement in the understanding of asthma/atopy pathogenesis will shed light on better control and treatment. VDR-deficient mice failed to develop experimental allergic asthma, suggesting a role for vitamin $\mathrm{D}$ in driving Th2 inflammation in the airways. ${ }^{30}$

In asthmatic patients, $\mathrm{T}$ cells and particularly $\mathrm{CD}^{+}$ lymphocytes are stimulated and switch from naïve to memory $\mathrm{CD}^{+}{ }^{+}$T cells. $^{7}$ The decreased level of vitamin $\mathrm{D}$ in asthma could be explained in part by CD4 cells consuming intrinsic vitamin D during their activation, as VDR expression on $\mathrm{CD}^{+} \mathrm{T}$ lymphocytes increases drastically after cell activation. ${ }^{23}$ Addition of $1,25(\mathrm{OH})_{2} \mathrm{D}_{3}$ leads to decreased secretion of IL- 2 and IFN- $\gamma$ by CD4 T cells and promotes IL-5 and IL-10 production, which further shifts the T cell response towards Th2 dominance. ${ }^{23,24}$ Importantly, immune cells are able to activate vitamin D locally, which indicates an autocrine or paracrine role for this vitamin within the immune system.

Lower levels of vitamin D in children were associated with increased markers of asthma severity. ${ }^{4}$ Several studies have reported associations of low vitamin D status with poor pulmonary function and increased incidence of respiratory infections, asthma, and chronic obstructive pulmonary disease. ${ }^{6}$ Mechanistic studies suggested that $1,25-(\mathrm{OH})_{2} \mathrm{D}_{3}$ influenced downregulation of the glucocorticoid receptor by its ligand. ${ }^{31,32}$ These studies suggest that vitamin D may have therapeutic potential in severe asthma patients as a steroid-enhancing agent. Emerging studies show an association between low vitamin D status and poor clinical responsiveness to glucocorticoids in asthma patients. ${ }^{33}$ If a steroid-enhancing role for vitamin $\mathrm{D}$ is proven, it is likely to be applicable to other chronic illness in which steroids represent a primary treatment, as also suggested by data on animal models. ${ }^{32}$ Nevertheless, considerable interest remains in the therapeutic application of vitamin D to asthma, and examples of beneficial effects exist.

The fact that Th1/Th2 ratio and Th17 were correlated to serum vitamin $\mathrm{D}$ raises a question about the origin of vitamin $\mathrm{D}$ deficiency in asthma. More studies are needed to clarify the mechanisms by which vitamin $\mathrm{D}$ regulates cellular immunity. Similarly, the genetic factors influencing $1,25(\mathrm{OH})_{2} \mathrm{D}_{3}$ production and vitamin $\mathrm{D}$ receptor expression should be explored. The microbial pattern-recognition receptor known as Toll-like receptor 9 (TLR9) was described as a biomarker of vitamin D-induced IL-10+ Tregs. Ligation of TLR9 with its agonist CpG (cytosine-phosphate-guanine) oligonucleotide turned off IL-10 production, suggesting a control mechanism abrogating Treg. ${ }^{33,34}$ The active form of vitamin D influences innate and adaptive immunity. It acts on APCs and T cells to promote peripheral tolerance through the inhibition of inflammatory responses and the induction of Treg cells. Recently, Wong et al reported that a coculture of bronchial epithelial cells and basophils could significantly induce the release of IL-6, an epithelial inflammatory cytokine as well as CCL2, a chemokine for basophils, eosinophils, and monocytes. ${ }^{35}$ This induction was synergistically enhanced by IL-17A. The interaction of basophils and bronchial epithelial cells was under IL-17A stimulation. It was differentially regulated by extracellular signal-regulated kinase, c-Jun $\mathrm{N}$-terminal protein kinase, p38 mitogen-activated protein kinase, and nuclear factor- $\kappa \mathrm{B}$ pathways. These findings suggest a new immunopathological role of Th17 cells and basophils in allergic asthma. ${ }^{35}$ Recently, Baeke et al reported that TX527 (hypocalcemic vitamin D analogs) directly affects human $\mathrm{T}$ cell function, thereby inhibiting effector $T$ cell reactivity while inducing regulatory $T$ cell characteristics, imprinting them with a specific homing signature favoring migration to sites of inflammation. ${ }^{36}$ These findings confirmed that vitamin $\mathrm{D}$ is an important regulator of immune function. T cells express the vitamin D receptor and have been shown to be direct and indirect vitamin D targets. ${ }^{37}$ Cantorna ${ }^{37}$ suggested that the expression of VDR is required for the development of two cell types, NKT cells and CD8 $\alpha \alpha$ T cells, which inhibit autoimmunity. In addition, effector T cell cytokine production is regulated by vitamin $\mathrm{D}$. 
The available evidence suggests that NKT and CD $8 \alpha \alpha$ T cells express VDR as part of the selection process to protect against the generation of autoimmunity. ${ }^{37}$

\section{Conclusion}

Our study provides important information on vitamin D levels in asthmatic children in the Mediterranean region. We were able to show that vitamin D deficiency in asthmatic patients is common, and it is similar to that seen in the autoimmune diseases. We found significant correlations between several inflammatory and immunological markers and vitamin D levels. These findings should be confirmed prospectively through the generation of an efficient multivariate model allowing further research about the use of vitamin D supplementation in patients with asthma.

\section{Acknowledgments}

Maalmi H, Berraïes A, Hamzaoui K, and Hamzaoui A contributed substantially to conception and design, or acquisition of data, or analysis and interpretation of data; Maalmi $\mathrm{H}$, Berraïes A, Hamzaoui K, and Hamzaoui A drafted the article or revised it critically for intellectual content; and Maalmi H, Berraïes A, Ammar J, Hamzaoui K, and Hamzaoui A had final approval of the version to be published.

\section{Disclosure}

The authors report no conflicts of interest in this work.

\section{References}

1. Li F, Peng M, Jiang L, et al. Vitamin D deficiency is associated with decreased lung function in Chinese adults with asthma. Respiration. 2011;81(6):469-475.

2. Chinellato I, Piazza M, Sandri M, Peroni D, Piacentini G, Boner AL. Vitamin D serum levels and markers of asthma control in Italian children. J Pediatr. 2011;158(3):437-441.

3. Chinellato I, Piazza M, Sandri M, et al. Serum vitamin D levels and exercise-induced bronchoconstriction in children with asthma. Eur Respir J. 2011;37(6):1366-1370.

4. Brehm JM, Schuemann B, Fuhlbrigge AL, et al. Serum vitamin D levels and severe asthma exacerbations in the Childhood Asthma Management Program study. J Allergy Clin Immunol. 2010;126(1):52-58. e5.

5. Lange NE, Litonjua A, Hawrylowicz CM, Weiss S. Vitamin D, the immune system and asthma. Expert Rev Clin Immunol. 2009;5(6): 693-702.

6. Holick MF. Vitamin D deficiency. N Engl J Med. 2007;357(3): 266-281.

7. Hewison M. Vitamin D and the intracrinology of innate immunity. Mol Cell Endocrinol. 2010;321(2):103-111.

8. Szeles L, Keresztes G, Töröcsik D, et al. 1,25-dihydroxyvitamin D3 is an autonomous regulator of the transcriptional changes leading to a tolerogenic dendritic cell phenotype. J Immunol. 2009;182(4): 2074-2083

9. von Essen MR, Kongsbak M, Schjerling P, Olgaard K, Odum N, Geisler C. Vitamin D controls $\mathrm{T}$ cell antigen receptor signalling and activation of human T cells. Nat Immunol. 2010;11(4):344-349.
10. Mora JR, Iwata M, von Andrian UH. Vitamin effects on the immune system: vitamins A and D take centre stage. Nat Rev Immunol. 2008;8(9):685-698.

11. Chambers ES, Hawrylowicz CM. The impact of vitamin D on regulatory T cells. Curr Allergy Asthma Rep. 2011;11(1):29-36.

12. Hamzaoui A, Maalmi H, Berraïes A, Abid H, Ammar J, Hamzaoui K. Transcriptional characteristics of CD4+ T cells in young asthmatic children: RORC and FOXP3 axis. J Inflamm Res. 2011;4:139-146.

13. Global strategy for asthma management and prevention: GINA executive summary. Eur Respir J. 2008;31(1):143-178.

14. Bischoff-Ferrari HA, Giovannucci E, Willett WC, Dietrich T, Dawson-Hughes B. 1. Estimation of optimal serum concentrations of 25-hydroxy vitamin D for multiple health outcomes. Am J Clin Nutr. 2006;84(1):18-28.

15. Hamzaoui K, Hamzaoui A, Guemira F, Bessioud M, Hamza M, Ayed K. Cytokine profile in Behçet's disease patients. Relationship with disease activity. Scand J Rheumatol. 2002;31(4):205-210.

16. Hamzaoui K, Houman H, Hamzaoui A. Regulatory T cells in cerebrospinal fluid from Behçet's disease with neurological manifestations. J Neuroimmunol. 2007;187(1-2):201-204.

17. Hamzaoui A, Ammar J, Hamzaoui K. Regulatory T cells in induced sputum of asthmatic children: association with inflammatory cytokines. Multidiscip Resp Med. 2010;5(1):22-30.

18. Black PN, Scragg R. Relationship between serum 25-hydroxyvitamin $\mathrm{D}$ and pulmonary function in the third national health and nutrition examination survey. Chest. 2005;128(6):3792-3798.

19. Zosky GR, Berry LJ, Elliot JG, James AL, Gorman S, Hart PH. Vitamin $\mathrm{D}$ deficiency causes deficits in lung function and alters lung structure. Am J Respir Crit Care Med. 2011;183(10):1336-1343.

20. Cannell JJ, Hollis BW, Zasloff M, Heaney RP. Diagnosis and treatment of vitamin D deficiency. Expert Opin Pharmacother. 2008;9(1):107-118.

21. Pappa HM, Grand RJ, Gordon CM. Report on the vitamin D status of adult and pediatric patients with inflammatory bowel disease and its significance for bone health and disease. Inflamm Bowel Dis. 2006;12(12):1162-1174.

22. Cantorna MT, Mahon BD. Mounting evidence for vitamin D as an environmental factor affecting autoimmune disease prevalence. Exp Biol Med. 2004;229:1136-1142.

23. Baeke F, Korf H, Overbergh L, et al. Human T lymphocytes are direct targets of 1,25-dihydroxyvitamin D3 in the immune system. J Steroid Biochem Mol Biol. 2010;121(1-2):221-227.

24. Yu S, Cantorna MT. The vitamin D receptor is required for iNKT cell development. Proc Natl Acad Sci U S A. 2008;105:5207-5212.

25. Maruotti N, Cantatore FP. Vitamin D and the immune system. J Rheumatol. 2010;37(3):491-495.

26. Poon AH, Laprise C, Lemire M, et al. Association of vitamin D receptor genetic variants with susceptibility to asthma and atopy. Am J Respir Crit Care Med. 2004;170(9):967-973.

27. Van Eerdewegh P, Little RD, Dupuis J, et al. Association of the ADAM33 gene with asthma and bronchial hyperresponsiveness. Nature. 2002;418(6896):426-430.

28. Lachheb J, Chelbi H, Hamzaoui K, Hamzaoui A. Toll-like receptors and CD14 genes polymorphisms and susceptibility to asthma in Tunisian children. Tissue Antigens. 2008;71(5):417-425.

29. Lachheb J, Chelbi H, Hamzaoui K, Hamzaoui A. Association between RANTES polymorphisms and asthma severity among Tunisian children. Hum Immunol. 2007;68(8):675-680.

30. Wittke A, Weaver V, Mahon BD, August A, Cantorna MT. Vitamin D receptor-deficient mice fail to develop experimental allergic asthma. J Immunol. 2004;173(5):3432-3436.

31. Lloyd CM, Hawrylowicz CM. Regulatory T cells in asthma. Immunity. 2009;31(3):438-449.

32. Xystrakis E, Kusumakar S, Boswell S, et al. Reversing the defective induction of IL-10-secreting regulatory $\mathrm{T}$ cells in glucocorticoidresistant asthma patients. J Clin Invest. 2006;116(1):146-155. 
33. Searing DA, Searing DA, Zhang Y, et al. Decreased serum vitamin D levels in children with asthma are associated with increased corticosteroid use. J Allergy Clin Immunol. 2010;125(5):995-1000.

34. Daniel C, Sartory NA, Zahn N, Radeke HH, Stein JM. Immune modulatory treatment of trinitrobenzene sulfonic acid colitis with calcitriol is associated with a change of a T helper (Th)1/Th17 to a Th2 and regulatory T cell profile. J Pharmacol Exp Ther. 2008;324(1):23-33.

35. Wong CK, Cao J, Yin YB, Lam CW. Interleukin-17A activation on bronchial epithelium and basophils: a novel inflammatory mechanism. Eur Respir J. 2010;35(4):883-893.
36. Baeke F, Korf H, Overbergh L, et al. The vitamin D analog, TX527, promotes a human CD4+CD25highCD127low regulatory $\mathrm{T}$ cell profile and induces a migratory signature specific for homing to sites of inflammation. J Immunol. 2011;186(1):132-142.

37. Cantorna MT. Why do T cells express the vitamin D receptor? Ann $N$ Y Acad Sci. 2011;1217:77-82.

\section{Publish your work in this journal}

The Journal of Asthma and Allergy is an international, peer-reviewed open-access journal publishing original research, reports, editorials and commentaries on the following topics: Asthma; Pulmonary physiology; Asthma related clinical health; Clinical immunology and the immunological basis of disease; Pharmacological interventions and

\section{Dovepress}

new therapies. Issues of patient safety and quality of care will also be considered. The manuscript management system is completely online and includes a very quick and fair peer-review system, which is all easy to use. Visit http://www.dovepress.com/testimonials.php to read real quotes from published authors.

Submit your manuscript here: http://www.dovepress.com/journal-of-asthma-and-allergy-journal 